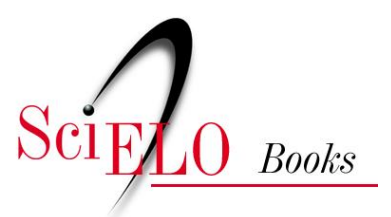

\title{
Ordem Clupeiformes
}

\author{
Ana Cristina Teixeira Bonecker \\ Claudia Akemi Pereira Namiki \\ Márcia Salustiano de Castro \\ Paula Nepomuceno Campos
}

\section{SciELO Books / SciELO Livros / SciELO Libros}

BONECKER, ACT., et al. Ordem Clupeiformes. In Catalogo dos estágios iniciais de

desenvolvimento dos peixes da bacia de Campos [online]. Curitiba: Sociedade Brasileira de Zoologia, 2014, pp. 31-33. Zoologia: guias e manuais de identificação series. ISBN 978-85-98203-10-2.

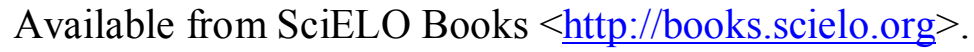

\section{(2)(1)(2)}

All the contents of this chapter, except where otherwise noted, is licensed under a Creative Commons Attribution-Non Commercial-ShareAlike 3.0 Unported.

Todo o conteúdo deste capítulo, exceto quando houver ressalva, é publicado sob a licença Creative Commons Atribuição Uso Não Comercial - Partilha nos Mesmos Termos 3.0 Não adaptada.

Todo el contenido de este capítulo, excepto donde se indique lo contrario, está bajo licencia de la licencia Creative Commons Reconocimento-NoComercial-CompartirIgual 3.0 Unported. 


\section{ORDEM CLUPEIFORMES}

A ordem Clupeiformes é composta por cinco famílias e aproximadamente 364 espécies. As características comuns da ordem são: corpo alongado e fino, intestino reto e estriado, distância pré-anal entre 50 e 95\% do comprimento do corpo, olho redondo, número de vértebras 38 a 54.

Nesse estudo a ordem Clupeiformes é representada pela família Engraulidae. 


\section{Família Engraulidae}

A família Engraulidae é pelágica e costeira. Ocorre nos oceanos Atlântico, Índico e Pacífico. Compreende duas subfamílias e 16 gêneros com 139 espécies. Dezessete espécies ocorrem em água doce, algumas são estuarinas e a maioria é marinha. As larvas de Engraulidae são alongadas e possuem vesícula gasosa proeminente. As principais características para separar as larvas de Engraulidae das larvas das famílias Clupeidae, Argentinidae, Bathylagidae e Phosichthyidae, que são muito semelhantes, são a distância pré-anal, a posição das nadadeiras dorsal e anal e o formato dos olhos. Nos engraulídeos o intestino alcança $75 \%$ do comprimento padrão, a origem da nadadeira anal e o final da nadadeira dorsal se sobrepõem e os olhos são redondos.

No Brasil já foram identificadas 17 espécies marinhas nas fases de larva e adulto. Nesse estudo é contemplada a espécie Engraulis anchoita. 


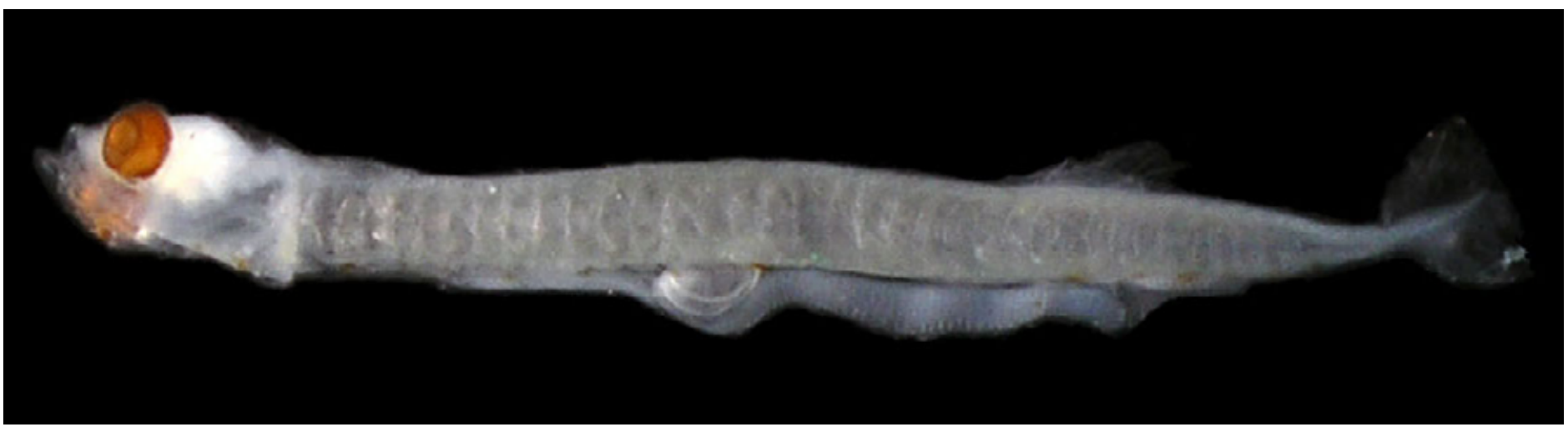

Figura 14: Engraulis anchoita DZUFRJ 31311; Pré-flexão; CP 5,5 mm.

\section{Engraulis anchoita Hubbs \& Marini, 1935}

Possui o corpo muito alongado e fino. O intestino é estriado e longo alcançando aproximadamente $75 \%$ do corpo. Apresenta um melanóforo no cleitro e logo acima da base da nadadeira peitoral. Possui melanóforos na região ventral anterior do corpo e na extremidade posterior da notocorda. O número de vértebras varia entre 44 e 48.

Tamanho: pré-flexão: 4,5-6,5 mm.

Habitat: espécie marinha e pelágica. Ocorre em profundidades entre 30 e $200 \mathrm{~m}$.

Nome vulgar: Anchoita.

\section{Georreferenciamento}

\begin{tabular}{|c|c|c|c|c|c|c|c|c|}
\hline DZUFRJ & Latitude (S) & Longitude (W) & Data & $\begin{array}{c}\text { Tipo de } \\
\text { arrasto }\end{array}$ & $\begin{array}{c}\text { Profundidade } \\
\text { de coleta }\end{array}$ & Rede & $\begin{array}{c}\text { Malha } \\
\text { ( } \boldsymbol{\mu m} \text { ) }\end{array}$ & $\begin{array}{c}\text { No. de } \\
\text { inds. }\end{array}$ \\
\hline 350 & $22^{\circ} 33^{\prime} 37,0^{\prime \prime}$ & $040^{\circ} 19^{\prime} 10,0^{\prime \prime}$ & $17 / 5 / 2002$ & oblíquo & $50 \mathrm{~m}$ & bongô & 330 & 2 \\
\hline 355 & $22^{\circ} 33^{\prime} 37,0^{\prime \prime}$ & $040^{\circ} 19^{\prime} 10,0^{\prime \prime}$ & $17 / 5 / 2002$ & oblíquo & $50 \mathrm{~m}$ & bongô & 500 & 2 \\
\hline 358 & $22^{\circ} 34^{\prime} 05,0^{\prime \prime}$ & $040^{\circ} 19^{\prime} 40,0^{\prime \prime}$ & $17 / 5 / 2002$ & oblíquo & $600 \mathrm{~m}$ & cilíndrico-cônica & 500 & 1 \\
\hline
\end{tabular}

Referências: Ciechomski, 1965; Phonlor, 1984. 